\section{Nature pictured}

\section{Charles A. Fleming}

Sydney Parkinson: Artist of Cook's

Endeavour Voyage.

Edited by D.J. Carr.

Nova Pacifica, Wellington/Australian

National University Press,

Canberra/Croom Helm, London: 1984.

Pp.300. NZ\$85, A\$49.95, £29.95.

BICENTENNIAL commemorations in 1969 , and the Hakluyt editions of Cook's Voyages (edited by J.C. Beaglehole, and published between 1955 and 1967), stimulated still further publication of pictures and descriptions that constitute the historical treasures of the lands James Cook made known to the Western world. To dwellers in the "new" countries of the Southern Hemisphere, these first European observations of our homelands are precious cultural resources, basic to understanding our history and the environments we have modified so severely.

Sydney Parkinson, whose life, sketches and paintings are the subject of this book, was already skilled as a nature artist when he joined Joseph Banks's team in 1767 at the age of 22. In the four remaining years of his life, Parkinson illustrated most of the natural curiosities collected on the voyage of the Endeavour, and also drew coastal landscapes for the Master's log. In New ADVERTISEMENT

PRACTICAL MACROMOLECULAR ORGANIC CHEMISTRY

by Diotrich Braun, Harald Cherdron and Worner Rern. Translated by Renneth J. Irvin

A volume in the MMI Press Polymer Monograph series

April 1984

339 pp.

19 C NMR SPECIROSCOPY

edited by Eberhord Breitmoir and Gorhard Bauer. Tranilated by Bruce $\mathrm{X}$. Coweol

A volume in the MMI Press Polymer

Monograph series

April 1984

$431 \mathrm{pp}$

\section{CHEMISTRY REVIEWS}

Soviet Sclentific Reviews Section B

edited by M.E. Volpin

Vol.5: April 1984

approx. 305 pp.

Vol.6: Summer 1984

3-7186-0137-0

$\$ 170.00$

approx. $385 \mathrm{pp}$.

SUBSCRIPTION FOR $\$ 140.00 \mathrm{PER}$

VOLUME

\section{ONIC HYDROGENATION AND}

\section{RET.ATED REACTIONS}

edited by D.N. Kureanov.

Z.N. Parnes, M.I. Zalinkin and

N.M. Loim. Tranglated by Leo Wiener

A.M. Lolm. Tranglated by 100 Wie

Supplement Series, Soviet Scientific

Reviews, Section $B$

Autumn 1984

approx. $230 \mathrm{pp}$

harwood academic publishers

12 Williani IV Stree

London WC2N 4DE. UK

50 West 23rd Str
NY 10010, USA
Zealand and Australia, the harvest of novelties was so rich that priorities were set; botany got preference over zoology, and Parkinson skilfully sketched pencil outlines with representative details coloured in, a shorthand technique that enabled artists in London to finish many of the plant pictures.

In his preface, D.J. Carr acknowledges the encouragement of the late Averil Lysaght, "clearly the writer of choice for a biography of Parkinson". Between them, the editor and Wilfrid Blunt cover Parkinson's life story very well, however, and Blunt also describes the Endeavour voyage using his text from Captain Cook's Florilegium (1973). Naturalist readers may jib at his ex cathedra judgement of Spöring's "pedestrian"' sketches and of his suspected use of a ruler (horreur!), while Blunt perhaps also underestimates the increasing interest in natural history during the past half-century in dismissing invertebrate pictures as of little interest to the general public.

Chapters 3 to 7 deal with plants of Madeira and South America (Edwards), Tahiti (Fosberg and Sachet), New Zealand (Godley), Australia (Henderson) and Java (Stearn). Each of these accounts consists of a double-column narrative text, in which illustrations are interspersed with extended single-column captions in smaller font, an at times somewhat confusing format. Chapters vary in style, Henderson giving etymology of Linnean names while other authors devote more space to history of nomenclature, biology or biogeography.

In his contribution on Parkinson's animal paintings, Alwyne Wheeler throws new light on the work of Banks's research team and offers explanations for their puzzling neglect of land animals in favour of plants. Wheeler also includes an account (and reproductions) of Parkinson's early copies of paintings of Ceylon animals (J.G. Loten coll.), some of which were later published by Pennant and by Forster. The paintings for Banks in 1767-1768 are not sampled, however, being already covered in Lysaght's Joseph Banks in Newfoundland and Labrador 1766. Parkinson's "meticulous accuracy and loving detail" in depicting insects and minute crustaceans from the plankton contrast markedly with his perfunctory sketches of kangaroos and other novel land vertebrates. Fishes dominate the 39 vertebrate drawings included here, most of which are beautiful colour reproductions though some are over-reduced and framed by too much blank paper.

The editor adds appendices on the identity of Cook's kangaroo(s), and on birds in Parkinson's sketchbook that were his own versions of species illustrated by George Edwards, in a work probably from the Endeavour's library. This links up with a short chapter on Malayan boats by G.A. Horridge, who identifies two folios from the sketchbook, showing outrigger boats with triangular sails, as Parkinson's renderings of the famous Marianas "flying proa", a style of vessel he never saw, already on the decline 40 years before Cook's voyage. Parkinson studied a diagram in a copy of Anson's Voyage (1748), saw it sailing "in his mind's eye" and drew perspective sketches.

The final chapter, "Coastal Profiles and Landscapes" by J.R.H. Spencer, is of special interest to New Zealanders. Spencer

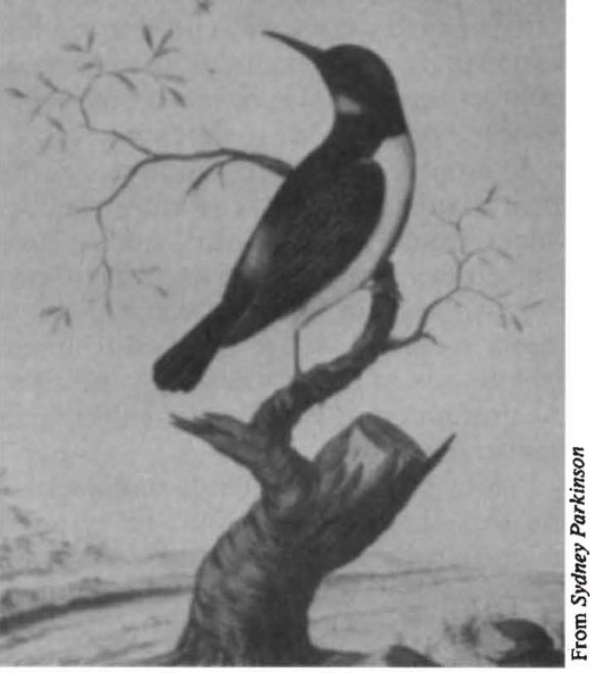

Purple-rumped sunbird (Nectarinia zeylonica), depicted by Sydney Parkinson, 1767.

compares Parkinson's sketches and romantic pen-and-wash drawings with Spöring's drawings and modern photographs of the Maori fortified paa at Motuarohia, Bay of Islands, supported by a site plan from his own surveys in 1974 . He demonstrates how Parkinson, minutely accurate in depicting coasts and scientific specimens, rearranged or supplemented the actual scene "to provide the elements of a pleasing composition".

Welcome as it is, the book has some annoying defects. How long must bibliophiles tolerate square books that fit no conventional bookshelf? On the dust cover, one of Parkinson's finest pictures is marred by (and obscures) the superposed lettering. (But, on the other hand, the endpapers are beautifully conceived and executed.) And while the much-reduced plates are exquisite, the yellowish-cream backgrounds (absent from Florilegium plates) sometimes obscure Parkinson's pencil outlines of details.

In each of the lands the Endeavour visited, naturalists without access to Banks's Florilegium will want complete coverage of that land's pictures; future demand is likely to be for separate works containing all of his drawings from each country in turn. Meanwhile, this volume gives overdue tribute to Sydney Parkinson and offers a wide selection of his work in one volume.

Sir Charles Fleming is Honorary Lecturer in Geology at the Victoria University of Wellington. From 1953 to 1977 he was Chief Palaeontologist to the New Zealand Geological Survey. 